\title{
LESION PATTERN ON MAGNETIC RESONANCE IMAGING AND STROKE ETIOLOGY IN MULTI-TERRITORIAL INFARCTIONS
}

\author{
Ethem Murat ARSAVA*, Lala MEHDIKHANOVA*, Rahşan GÖÇMEN**, \\ Kader KARLI OĞUZ**, Mehmet Akif TOPÇUOĞLU* \\ * Hacettepe University Faculty of Medicine, Department of Neurology, Ankara, TURKEY \\ ** Hacettepe University Faculty of Medicine, Department of Radiology, Ankara, TURKEY
}

\begin{abstract}
INTRODUCTION: Presence of ischemic lesions in multiple vascular territories is suggestive of an embolic etiology, which could therefore necessitate a detailed etiologic work-up to uncover the underlying pathology. Lesion patterns on diffusionweighted imaging (DWI) might be used as a marker of certain stroke etiologies and guide the clinician in prioritizing diagnostic investigations. In this study, we sought to identify the relationship between certain lesion characteristics on DWI and stroke etiologies in a consecutive series of ischemic stroke patients with multi-territorial lesions.

METHODS: Patients with acute and subacute ischemic lesions simultaneously present in multiple cerebral arterial territories were retrospectively identified from a departmental database. The distribution, number and size of these lesions, and their association with different stroke etiologies were assessed for all patients.

RESULTS: A total of 74 patients were included into the study. Patients with 'other' causes of stroke more commonly had lesions distributed in all cerebral arterial territories $(p=0.02), \geq 10$ lesions $(p<0.01)$ and a heterogeneous pattern composed of multiple small and large lesions $(\mathrm{p}=0.03)$ when compared to the remaining patients. In contrast, patients with undetermined/unclassified origin of stroke had lower number of lesions $(p<0.01)$ that were distributed mainly in only two circulations $(\mathrm{p}=0.04)$ and were primarily homogenously small in nature $(\mathrm{p}<0.01)$.

DISCUSSION and CONCLUSION: Lesion patterns on DWI are significantly associated with certain stroke etiologies in patients with multi-territorial infarctions, and therefore might be used in planning of the diagnostic work-up in such cases. Keywords: Brain imaging, cerebral infarct, coagulopathy, diffusion-weighted imaging, embolism.
\end{abstract}

\section{COKLU SULAMA ALANI ENFARKTLARINDA MANYETIK REZONANS GÖRÜNTÜLEME LEZYON PATERNI VE İNME ETIOLOJISI}

\section{ÖZET}

GİRIŞ ve AMAÇ: İskemik inme ile başvuran hastalarda birden fazla arter sulama alanında iskemik lezyon varlığı embolik bir etiyolojiye işaret etmekte ve detaylı bir emboli kaynağı araștırmasını beraberinde getirmektedir. Difüzyon ağırlıklı görüntülemelerde (DAG) gözlenen lezyon paternleri klinisyenlere belirli inme etiyolojilerini düşündürebilir ve bu anlamda diyagnositk incelemelere yön vermek için kullanılabilir. Bu çalışmada birden fazla arter sulama alanında iskemik lezyonu olan hastalarda, DAG lezyon paterni ve inme etiyolojisi arasındaki ilişki incelenmiştir.

YÖNTEM ve GEREÇLER: Bölümümüz inme veri tabanından birden fazla serebral arter sulama alanında akut veya subakut iskemik lezyonları olan hastalar retrospektif olarak taranarak saptanmıștır. Bu hastalardaki inme etiyolojileri ve DAG incelemelerindeki lezyon boyutları, dağılımları ve sayıları arasındaki ilişki incelenmiştir.

BULGULAR: Çalışmaya 74 hasta dahil edilmiștir. Etiyolojik incelemeler sonucunda 'diğer nadir inme nedenleri' alt grubunda sinıflandırılan hastalarda tüm serebral arter sulama alanlarında lezyon varlığı $(\mathrm{p}=0,02), \geq 10$ lezyon sayısı $(p<0,01)$, küçük ve büyük lezyonların bir arada olduğu heterojen lezyon paterni $(p=0,03)$ daha sık gözlendi. Nedeni aydınlatılamayan/sınıflandırılamayan inme hastalarında ise daha az lezyon sayısı $(\mathrm{p}<0,01)$, iki dolaşıma sınırlı lezyon dağılımı $(p=0,04)$ ve esas olarak küçük lezyonlardan oluşan homojen bir patern $(p<0,01)$ dikkati çekmekte idi.

TARTIŞMA ve SONUÇ: Çoklu arter sulama alanı enfarktı olan hastalarda DAG incelemelerindeki lezyon paternleri belirli etiyolojiler ile yakın ilişki göstermektedir; bu paternler etiyolojik incelemeler esnasındaki önceliklerin belirlenmesi konusunda yardımcı olabilir.

Anahtar Sözcükler: Beyin görüntülemesi, serebral enfarkt, koagülopati, difüzyon ağırlıklı görüntüleme, embolism.

Corresponding author: Ethem Murat Arsava, Prof. MD. Hacettepe University, Faculty of Medicine, Department of Neurology, 06100 Sihhiye, Ankara, Turkey. Telephone: +903123051806 E-mail: arsavaem@hotmail.com

Received: 19.06.2018 Accepted: 18.07.2018

This article should be cited as following: Arsava E.M, Mehdikhanova L, Göçmen R, Karlı Oğuz K, Topçuoğlu M.A. Lesion pattern on magnetic resonance imaging and stroke etiology in multi-territorial infarctions. Turkish Journal of Cerebrovascular Diseases 2018; 24 (3): $94-97$. doi: 10.5505/tbdhd.2018.30502 


\section{INTRODUCTION}

The presence of multiple acute/subacute ischemic lesions on magnetic resonance imaging (MRI) within different vascular territories is highly suggestive of an embolic stroke etiology. Although the source of embolism might be obvious in some patients, determination of the underlying pathology could be labor intensive and time consuming in other cases as it might require a thorough evaluation of the aortic arch, heart and coagulation cascade, among many other factors (1). Indeed, a stroke etiology could not be identified in 15 to $59 \%$ of such cases (2-5). Lesion characteristics on MRI are related to certain stroke etiologies and might therefore guide the clinician in prioritizing etiologic investigations (4). In this study, our aim was to identify the relationship between lesion patterns and stroke etiologies in patients with acute/subacute lesions in multiple cerebral arterial territories.

\section{MATERIAL AND METHODS}

We retrospectively analyzed a consecutive series of patients with a diagnosis of ischemic stroke who were evaluated in our center between September 2009 and August 2011. Patients were identified from a departmental database to which all patients with a diagnosis of transient ischemic attack or stroke are registered. The study was limited to patients who had undergone diffusionweighted magnetic resonance imaging (DWI) within 2 weeks of symptom onset and who had multiple acute and/or subacute ischemic lesions in different cerebral arterial territories (ischemic lesions in both right and left anterior circulations or in both anterior and posterior circulations). Angiographic studies of all patients were reviewed to exclude anatomic variations in the circle of Willis that might explain the multi-territorial appearance of lesions. The study was approved by the institutional review board.

Demographic and clinical data were abstracted from the database. Stroke etiology was determined according to the Causative Classification of Stroke System (6). MRI was performed using $1.5 \mathrm{~T}$ scanners (Magnetom TIM, Siemens, Erlangen, Germany and Intera, Achieva, Philips, Netherlands). DWI employed single shot echo planar imaging (TR/TE: 4800/120ms, matrix: 96-256, slice thickness: $5 \mathrm{~mm}$, inter-slice distance: $10 \%$, FOV: $220-240 \mathrm{~mm}$ ), and applied three b values with a maximum of $1000 \mathrm{~s} / \mathrm{mm} 2$. Apparent diffusion coefficient (ADC) maps were obtained on the main console immediately after acquisition. Lesions hyperintense on DWI and hypointense on ADC maps were considered as acute, while lesions hyperintense on DWI and isointense on ADC maps were considered as subacute. These lesions were then classified according to their distribution, number and size. Lesions confined to right and left anterior circulations or right/left anterior circulation and posterior circulation were categorized as biterritorial, while lesions in both anterior circulations together with lesions in the posterior circulation were categorized as tri-territorial. Isolated subcortical lesions in territories of single penetrating arteries and cortical/juxtacortical lesions in territories of distal pial arteries were considered as small, while all the remaining lesions including ones that had both cortical and subcortical components as large lesions.

All numerical values are expressed as median and interquartile range (IQR). Chi-square test was used to compare imaging characteristics between different stroke subtypes. A p-value of $<0.05$ was considered significant. All statistical analyses were performed by SPSS 16.0.

\section{RESULTS}

There were 587 ischemic stroke patients who underwent MRI during the study period. Of these patients, 74 (13\%) with simultaneous infarcts in multiple vascular territories and MRI within two weeks of symptom onset comprised the study population.

Clinical and imaging characteristics of the study population are summarized in Table I. The most common stroke etiology responsible for multiple lesions simultaneously involving different circulations were 'other' causes; these included 17 patients with hypercoagulability (10 patients with established malignancy, six patients with occult malignancy, one patient with protein $\mathrm{C}$ and $\mathrm{S}$ deficiency), 11 patients with a recent endovascular or surgical procedure, and one patient each with radiation induced vasculopathy, vasospasm, cardiac arrest and thrombotic thrombocytopenic purpura. Stroke etiology was undetermined in 25 patients (34\%), while the underlying etiology was cardio-aortic embolism in 12 patients (16\%), 
large-artery atherosclerosis in $4(5 \%)$ patients and unclassified in one patient (1\%). Lesions were distributed in two different circulations in 39 patients (53\%) and in all circulations in 35 patients $(47 \%)$. The median (IQR) number of lesions was 11 (6-32). Most patients (39 patients, $53 \%$ ) had multiple small lesions accompanied by one or more large lesions.

The relationship between lesion characteristics and stroke etiology is summarized in Table II. The heterogeneity of lesion characteristics among stroke subtypes primarily arose from lesions observed in patients with 'other' causes of stroke and undetermined/unclassified cases. Patients with 'other' causes of stroke more commonly had lesions distributed in all cerebral arterial territories $(\mathrm{p}=0.02), \geq 10$ lesions $(\mathrm{p}<0.01)$ and $a$ heterogeneous pattern composed of multiple small and large lesions $(\mathrm{p}=0.03)$. This was in contrast to patients with undetermined/unclassified origin of stroke, where lower number of lesions were distributed mainly in only two circulations and were primarily homogenously small in nature ( $\mathrm{p}<0.01, \mathrm{p}=0.04$, and $\mathrm{p}<0.01$, respectively) (Figure). We were not able to document any lesion characteristics significantly associated with large artery atherosclerosis or cardio-aortic embolism.

Table I. Clinical and imaging characteristics of the study population.

\begin{tabular}{lc}
\hline Age & $64(53-76)$ years \\
Gender & 37 female (50\%) \\
Risk Factors & 37 male $(50 \%)$ \\
$\quad$ Hypertension & $48(65 \%)$ \\
Diabetes Mellitus & $28(38 \%)$ \\
Coronary Heart Disease & $24(32 \%)$ \\
$\quad$ Atrial Fibrillation & $5(7 \%)$ \\
Admission NIHSS score & $4(1-12)$ \\
Time from symptom onset to MRI & $25(11-66)$ hours \\
CCS Stroke Subtype & \\
Large Artery Atherosclerosis & $4(5 \%)$ \\
Cardioaortic Embolism & $12(16 \%)$ \\
Small Artery Occlusion & $0(0 \%)$ \\
Other Causes & $32(43 \%)$ \\
Undetermined/Unclassified & $26(35 \%)$ \\
Lesion Distribution & \\
Bi-territoral & $39(53 \%)$ \\
Tri-territorial & $35(47 \%)$ \\
Lesion Number & $11(6-32)$ \\
Lesion Size & \\
Small lesions without & $31(42 \%)$ \\
accompanying large lesion(s) & \\
Small lesions with accompanying & $39(53 \%)$ \\
large lesion(s) & \\
Other & $4(5 \%)$ \\
\hline
\end{tabular}

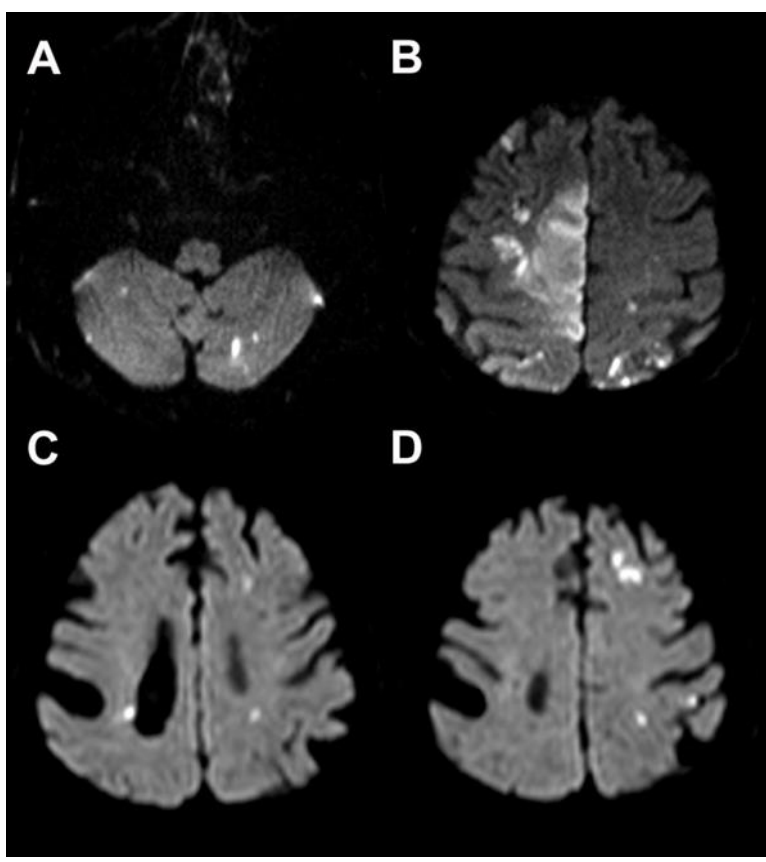

Figure A, B: DWI reveals numerous acute and subacute ischemic lesions of variable sizes in all vascular territories in a patient diagnosed with adenocarcinoma of unknown origin after presenting with stroke. C, D: Multiple small ischemic lesions restricted to two cerebral arterial territories in a patient with cryptogenic embolism.

\section{DISCUSSION}

Our findings show that in patients with simultaneous acute/subacute ischemic lesions in multiple vascular territories, presence of a combination of multiple small and large lesions distributed in all territories and high lesion burden are suggestive of stroke etiologies like hypercoagulability or iatrogenic procedures. On the other hand presence of $<10$ lesions, biterritorial distribution and homogenously small lesions are more often observed in patients with undetermined/unclassified stroke etiology.

Thirteen percent of patients in our ischemic stroke cohort had ischemic lesions distributed in more than one vascular territory, which was very similar to prior reports in the literature (2-5). The most common stroke etiology was other causes by $43 \%$, primarily secondary to hypercoagulability and interventional/surgical procedures. This was significantly higher when compared to previous literature $(2-5,7)$ and might be secondary to the fact that our cohort not only included admissions to the emergency department, but also included patients suffering from stroke while being admitted for other diagnoses. Multi-territorial 
